\title{
An analysis of energy saving through delamping method
}

\author{
Mohd Firdaus Mohd Ab Halim¹, Muhamad Faizal Yaakub², Mohamad Haniff Harun ${ }^{3}$, Khalil Azha \\ Mohd Annuar ${ }^{4}$, Farriz Hj Md Basar ${ }^{5}$, Mohd Nazri Omar ${ }^{6}$ \\ 1,2,3,4.5 Center for Robotics and Industrial Automation, Universiti Teknikal Malaysia Melaka, Malaysia \\ ${ }^{6}$ Pusat Pengajian Kejuruteraan Pembuatan, Universiti Malaysia Perlis, Malaysia
}

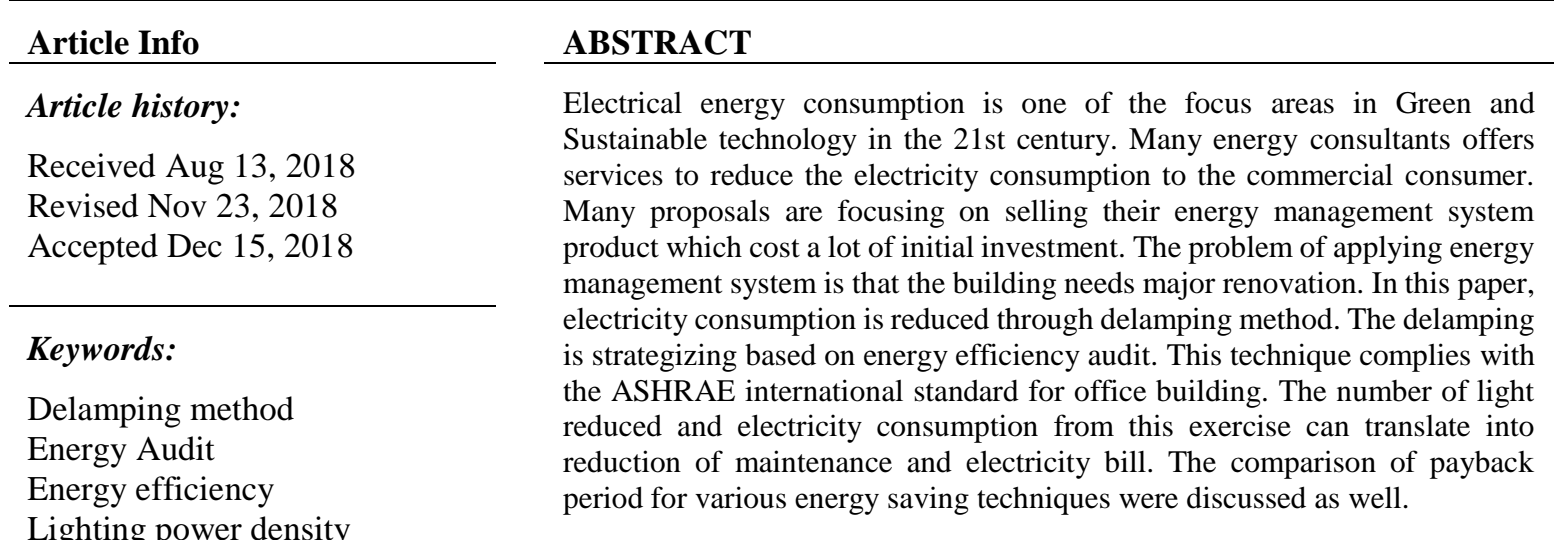

Copyright () 2019 Institute of Advanced Engineering and Science. All rights reserved.

\section{Corresponding Author:}

Mohd Firdaus Mohd Ab Halim,

Faculty of Engineering Technology,

Universiti Teknikal Malaysia Melaka,

76100 Durian Tunggal Melaka, Malaysia.

Email: mohd.firdaus@utem.edu.my

\section{INTRODUCTION}

In the latest united nation conference on climate change, 195 nations gathered in Paris to show their commitment on reducing greenhouse gas emission [1]. Many countries had set out specific measures to reduce the energy generation from the conventional power plant as it is the main causes of the world environmental impact. One of the measures planned by many countries was to reduce the energy consumption of all buildings through country's energy policy and regulation. The efficient management of electrical energy regulation 2008 is one of the tools to show Malaysia's pledge to contribute to a greener world by reducing the carbon emission intensity by $40 \%$ by the year 2020 . One of the key initiatives by Malaysia's government is to implement energy audit in building and industries [2]. Energy represents nearly 30\% of total expenditures for the typical administrative building, which is a significant operational cost deserving of management attention [3]. Tackling these expenses would not only reduce the operational cost but also in line with the pledge made by the authority. Average electricity consumption breakdown (\%) is shown in Figure 1. The potential energy saving can come from any of the load. There are many ways to reduce the electricity bills in administrative building such as through energy awareness campaign, replacing low efficiency appliance with a better efficiency, increase the set-point of the HVAC system and etcetera.

Lighting system contributes about $20 \%$ of the total energy expenses in commercial building. In this paper, the delamping method is proposed to reduce electricity bill in office building. There are many research article discuss about the possibility of managing the light efficiently through the use of sensor, timer, and the use of LED. Intelligent lighting system in [5] clarified that the problem of implementing the intelligent lighting system is the actual wiring of the building is complex. Hence, adopting the same system to other office building is not possible unless the wiring configuration is identical. Furthermore, the sensing module to provide input to the controller is not cheap. 


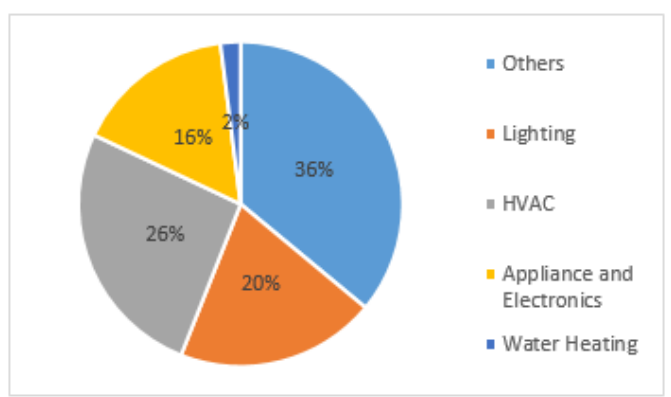

Figure 1. Electricity consumption breakdown in 2013 [4]

Lighting system energy efficiency can be achieved also by replacing the lamp type according to the human visual condition. The study in [6] focuses on the street lighting system as it represents the condition of photopic and scotopic. The study found that the Metal Halide (MH) lamp has the lowest implementation cost over 10 years. However, MH lamp lost $50 \%$ of its light output at 20,000 hours. Considering this fact, LED is still cost effective over 5 year's period and above. Another study made by [7] used DIALux simulation software to evaluate the efficient lighting scheme for the office buildings through the use of different types of lamps. Based on the simulation result, LED gives the most energy efficient lighting system type for office building. In [8], the study compares the conventional lighting system design of office building versus the Thailand Energy Ministry standard and regulation. Three different sizes of office building were chose to simulate the power of lighting system by various cases, according to illumination standard, and the performance index in term of $\mathrm{w} / \mathrm{m}^{2}$. The simulation result shows that the conventional design does not meet the minimum requirement of the Energy Conservation, Act B.E.2552. In [9], delamping method was used to remove a lamp from a total of 6 lamp in a $46.84 \mathrm{~m}^{2}$ area.

\section{RESEARCH METHODOLOGY}

\subsection{Location}

The lighting system energy audit was performed at Level 1 west wing administration block of the technology campus Universiti Teknikal Malaysia Melaka. We selected this building because it is easy to access and we have many information about building layout, number of tenant and average working hour. The building owner had renovated the building as requested by the faculty to become the lecturer offices.

\subsection{Research data}

A comprehensive room data survey should include other data collection such as temperature, number of appliances connected to the same kilowatt meter and relevant electrical parameters. Figure 2 shows the room data survey during annual energy audit.

\begin{tabular}{|c|c|c|c|c|c|c|c|c|c|c|c|c|c|}
\hline \multirow[b]{2}{*}{ No. } & \multirow[b]{2}{*}{ Room Function } & \multirow[b]{2}{*}{$\begin{array}{l}\text { Area } \\
\left(\mathrm{m}^{2}\right)\end{array}$} & \multirow[b]{2}{*}{\begin{tabular}{|l|} 
Temp \\
eratur \\
e $\left({ }^{\circ} \mathrm{C}\right)$
\end{tabular}} & \multirow[b]{2}{*}{$\begin{array}{c}\text { Number of } \\
\text { users }\end{array}$} & \multicolumn{4}{|c|}{ Lamp } & \multicolumn{5}{|c|}{ Other Equipment } \\
\hline & & & & & Type & $\begin{array}{l}\text { Power } \\
\text { (Watt) }\end{array}$ & Quantity & $\begin{array}{l}\text { Usage } \\
\text { hours) }\end{array}$ & No. & Name & $\begin{array}{l}\text { Power } \\
\text { (Watt) }\end{array}$ & Quantity & $\begin{array}{l}\text { Usage } \\
\text { hours) }\end{array}$ \\
\hline & Level 1 Left Wing & 1300 & 25 & 62 & T8 & $36 \mathrm{~W}$ & 296 & 9 & 1 & Socket & & 124 & \\
\hline 1 & Lecturer Room Area & & & & T8 & $36 \mathrm{~W}$ & 51 & & & PC & & 62 & \\
\hline & & & & & & & & & & AVR & & 62 & \\
\hline & & & & & & & & & & Mesin Fotostat & & 1 & \\
\hline & & & & & $E / L$ & 16 & & & & & & & \\
\hline & & & & & EXIT & 4 & & & & & & & \\
\hline 2 & Surau (L) & & & & T8 & $36 \mathrm{~W}$ & 1 & & & & & & \\
\hline 3 & Pantry & & & & T8 & $36 \mathrm{~W}$ & 6 & & & Socket & & 13 & \\
\hline 4 & Bilik AHU & & & & T8 & $36 \mathrm{~W}$ & 3 & & & & & & \\
\hline 5 & Toilet (p) & & & & T8 & $36 \mathrm{~W}$ & 5 & & & Socket & & 1 & \\
\hline 6 & Toilet (L) & & & & D/L & & 6 & & & Socket & & 1 & \\
\hline 7 & Bilik Housekeeping & & & & T8 & $36 \mathrm{~W}$ & 2 & & & Socket & & 4 & \\
\hline 8 & Bilik Seminar & & & & T8 & $36 \mathrm{~W}$ & 93 & & 1 & Projector & & 1 & \\
\hline
\end{tabular}

Figure 2. Room data survey of level 1 west wing administration block of the technology campus Universiti Teknikal Malaysia Melaka 


\subsection{Lighting layout}

The way the lighting system installed in this building is shown in Figure 3(a). Each square represent the ceiling size, $4 \mathrm{~m} \times 2 \mathrm{~m}$. The lamp fixtures were fitted on the ceiling. Figure 3(b) is the light distribution curve of the simulated luminaire and Figure 4 shows the distribution of the lamp across the office building. The yellow square represent the lamp fixture consist of two T8 lamps of 36W.

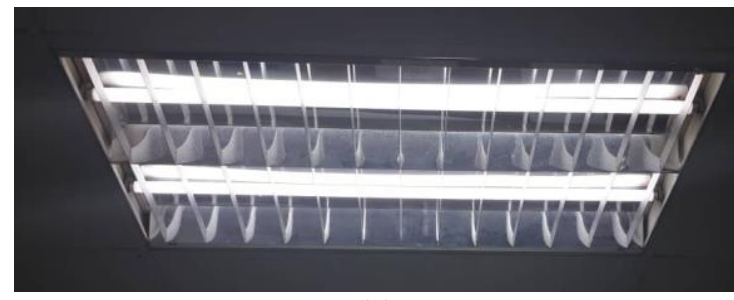

(a)

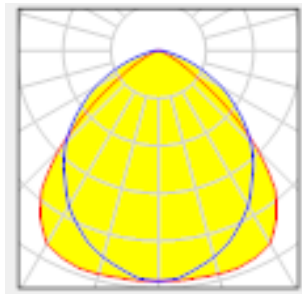

(b)

Figure 3. (a) Lighting system fitted a the ceiling (b) Light distribution curve for selected luminaire

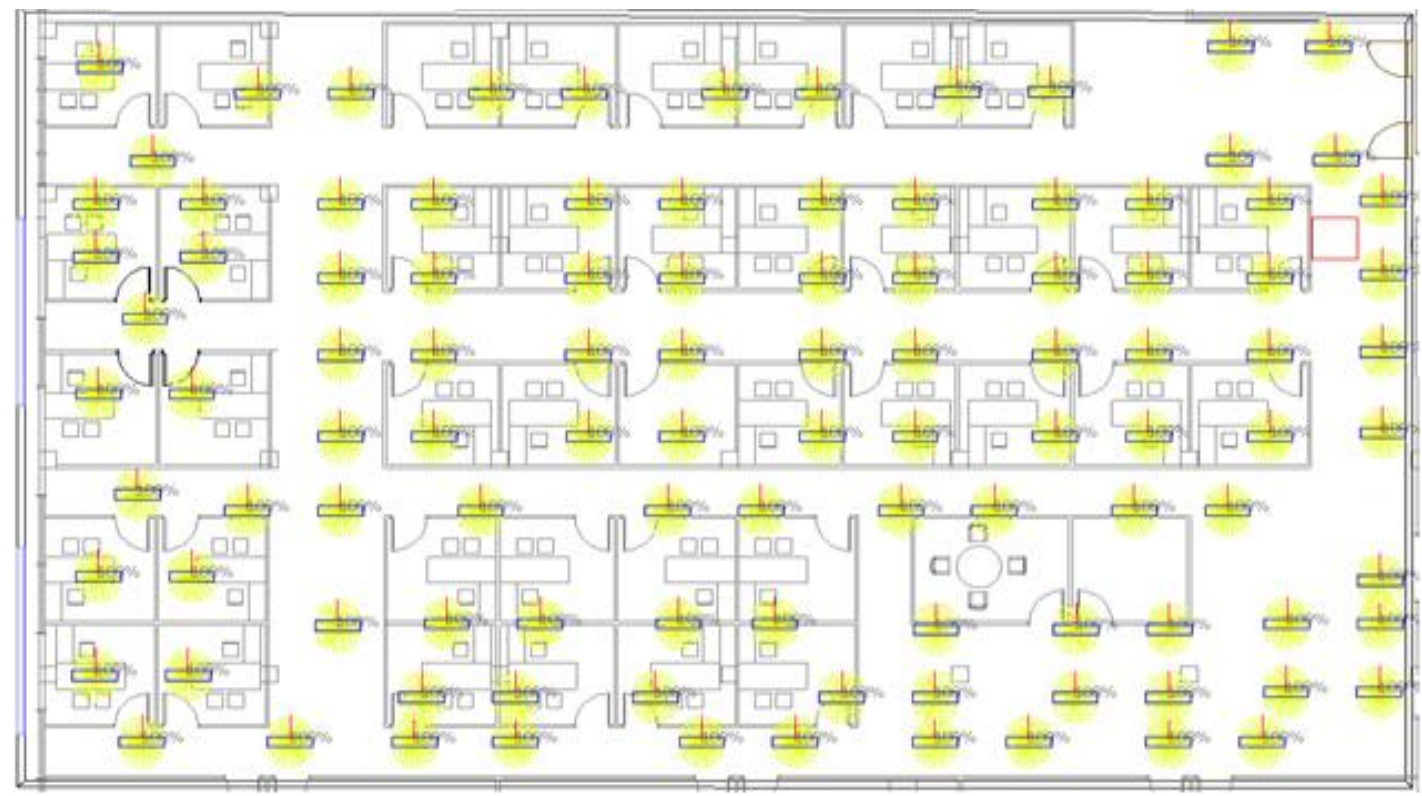

Figure 4. Lamp distribution at the focus location drawn in Dialux

\subsection{Energy auditing}

The lighting power density, (LPD) for this location is equals to $0.956 \mathrm{~W} / \mathrm{m}^{2}$. The actual value confirms that the office building lighting system is energy efficient. The energy audit data is reconfirmed with DIALux simulation result. The illuminance level for this area is shown in Figure 5. The illuminance level were high at some area and low at other area. The smallest lux level registered is 220 lux while the highest is 550 lux. The average lux for this area is 358 lux. The light fixture is arranged according to the real layout of the office. The luminaire used in this simulation is summarized in Table 1. The room geometry is in Table 2.

Table 1. Luminaire Selection

\begin{tabular}{ll}
\hline Variable & Luminaire Parameters \\
\hline Brand & Panasonic 2 x FL36W \\
Article No & FAC42781ENHE \\
Quantity & 115 units \\
Wattage & $72 \mathrm{~W}$ \\
Luminous flux & $3060 \mathrm{~lm}$ \\
Fitting & $2 \times$ YZ36RN (Correction Factor 1.000) \\
\hline
\end{tabular}

Table 2. Room Geometry

\begin{tabular}{ll}
\hline Variable & Geometry /Values \\
\hline Room Height & $2.800 \mathrm{~m}$ \\
Mounting Height & $2.875 \mathrm{~m}$ \\
Maintenance Factor & 0.80 \\
Ground Area & $791.7 \mathrm{~m}^{2}$ \\
\hline
\end{tabular}




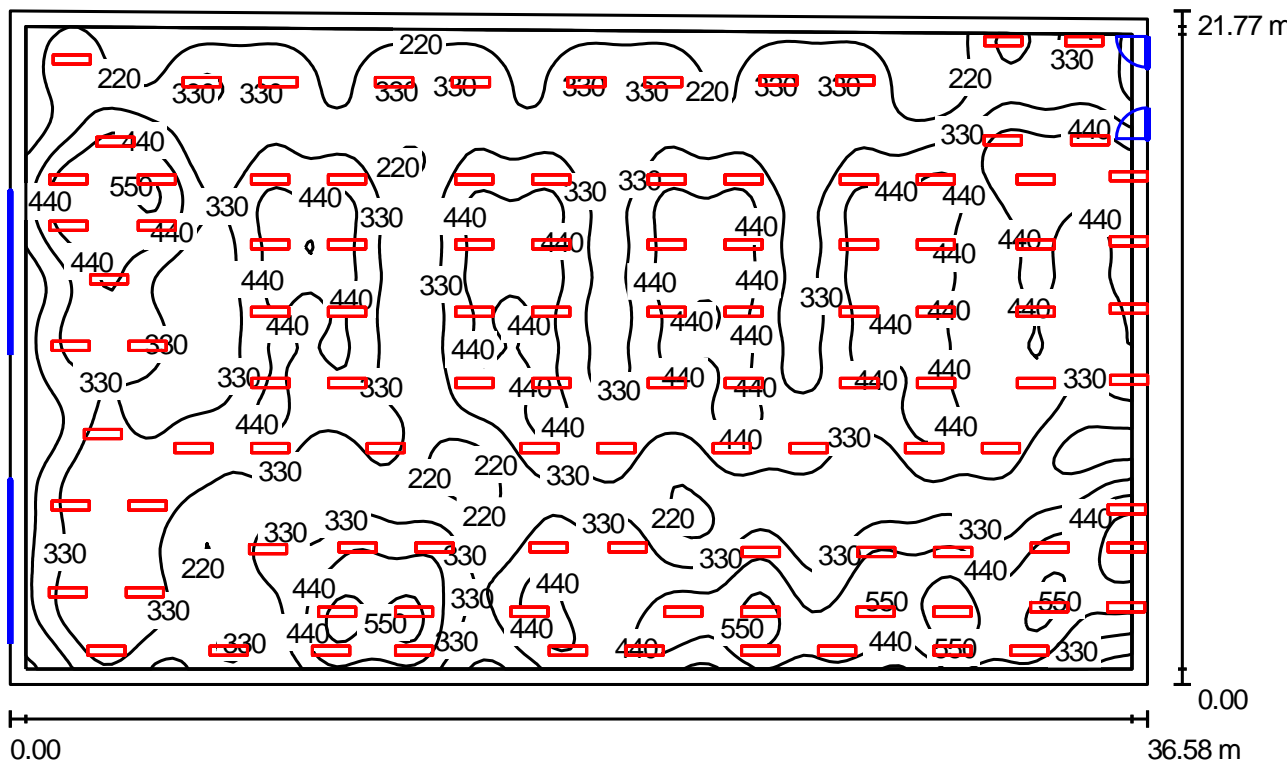

Figure 5. Illumination level of the office area

\subsection{Delamping Strategy}

Energy commission in many countries imposes limits on the amount of lighting power installed in the building to promote efficient technology and design. Table 3 shows the LPD limit for different type of building [10]. An office area should not exceed the LPD of $0.9 \mathrm{~W} / \mathrm{m}^{2}$. We obtained $0.887 \mathrm{~W} / \mathrm{m}^{2}$ but the lower the LPD the higher the saving we could get. To calculate the number of lamps to be removed, the extra lumens is divided with the the lumens per lamp which yield 4.37 lamps.

Number of lamps to be removed $=\frac{\text { Number of Lamp installed } \times \text { lumens }- \text { Required lumens }}{\text { lumens }}$

Table 3. LPD Limits for Different Type of Building

\begin{tabular}{lc}
\hline Building Type & $\begin{array}{c}\text { Maximum Lighting Power Density }\left(\mathrm{W} / \mathrm{ft}^{2}\right) \text { Allowed Version of the } \\
\text { ASHRAE/IES } 90.1 \text { Standard in } 2010\end{array}$ \\
\hline Dormitory & 0.61 \\
Hospital & 1.21 \\
Manufacturing Facility & 1.11 \\
Office & 0.90 \\
Retail & 1.40 \\
School/University & 0.99 \\
\hline
\end{tabular}

\section{RESULTS AND ANALYSIS}

To further improve the lighting system efficiency, the office location can be divided into two zones, the zone where it involves working on computer, 400-500 lux and passageways between office cubicles 100-150 lux. By rearranging the light according to the task, we could reduce the lighting set thus the NPD values. Figure 6 shows the proposed lamp reduction denoted by green circle area (green isolines labelled in green circle) where the illuminance level is above 500 lux. By considering the task for the given spot, we propose to remove one lamp at every passageways that register illumination values of 400-500 lux. The new NPD after the lamp reduction activities is 0.8447 . Annual utility bill saving A is

$$
A=n P U \times T
$$

where $n$ is the number of lamp reduced $=5$ units, $\mathrm{P}$ is lamp power rating $=72 \mathrm{~W}, \mathrm{U}$ is the annual usage $=2080$ hours and $\mathrm{P}$ is the average Tariff $=\$ 0.15$ (USD). Substituting the values yield a saving of $\$ 111.43$ or $5 \%$ electricity bill reduction. The tariff is assumed to be $\$ 0.15$. Besides the bill reduction, the carbon footprint 
would also reduce by the same percentage. The saving can further increased if different luminaire and mounting type is applied at specific location. The natural daylight is not accounted because not all tenant raised the window curtain to allow sunlight to support the internal lighting system. Nevertheless, it can be included in future investigation combining probability study. The bigger the area, the higher the benefits to the building owner. The labour cost for each lamp relocation is \$6.00. Hence within 3 months the investment has recovered. Table 4 compares the investment cost and saving for the area size $8571 \mathrm{~m}^{2}$ (similar area and layout as in Figure 4). Figure 7 shows the projection of saving for 3 different lighting system.

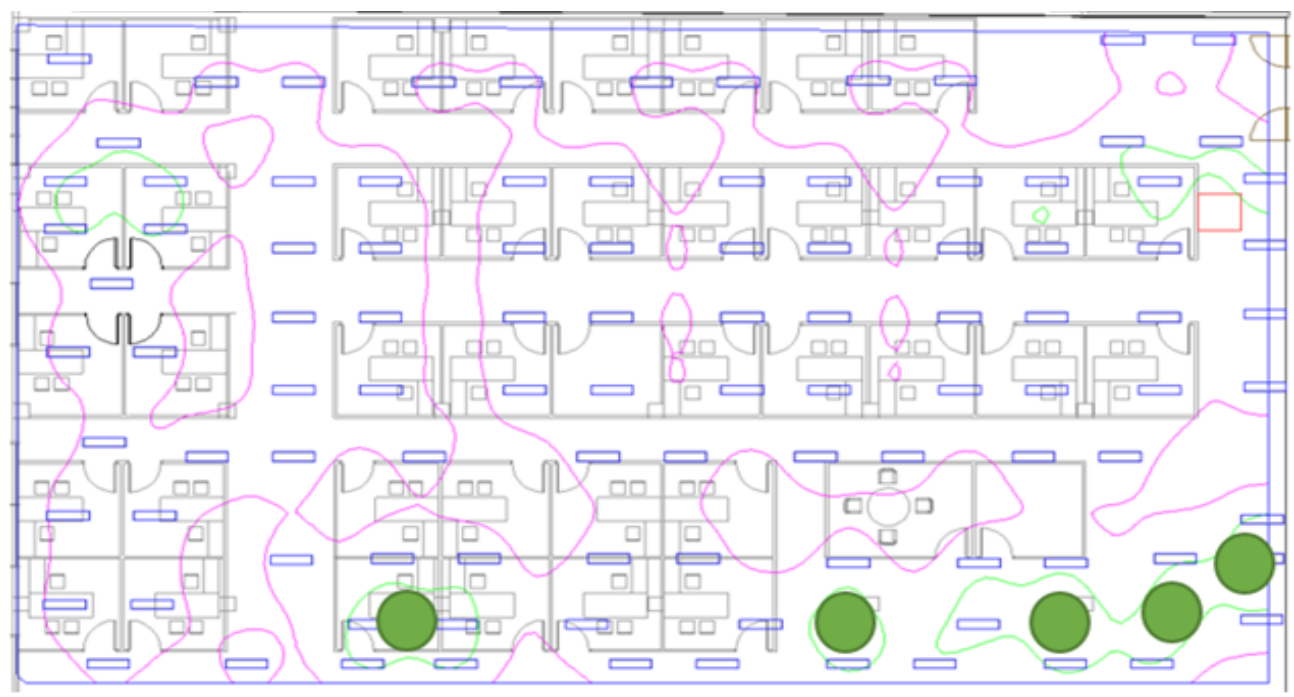

Figure 6. Proposed lamp reduction denoted by green circle

Table 4. Yearly Saving and Investment for Different Lighting System

\begin{tabular}{llll}
\hline Method of lighting system & $\begin{array}{l}* \text { Motion sensor control switch } \\
\text { in the corridor (4 hours) }\end{array}$ & $\begin{array}{l}\text { **trofit 196 units of } \\
\text { CFL to LED }\end{array}$ & $\begin{array}{l}\text { Delamping }- \text { relocate lamp and } \\
\text { remove redundancy }\end{array}$ \\
\hline Saving (USD) & 202 & 792.5 & 111.43 \\
Investment (USD) & 540 & 5880 & 30 \\
Payback period (years) & 2.6 & 7 & 0.3
\end{tabular}

*18 units of lamp at the main corridor consumption reduced to 50\% when motion sensor are installed in that area. Motion sensor cost per light $\$ 15$

**72 Watt CFL equivalent to 26 Watt LED. 98 units of CFL bulb is replaced with 98 units of LED bulb. T8 LED bulb is 4 times more expensive than normal CFL.

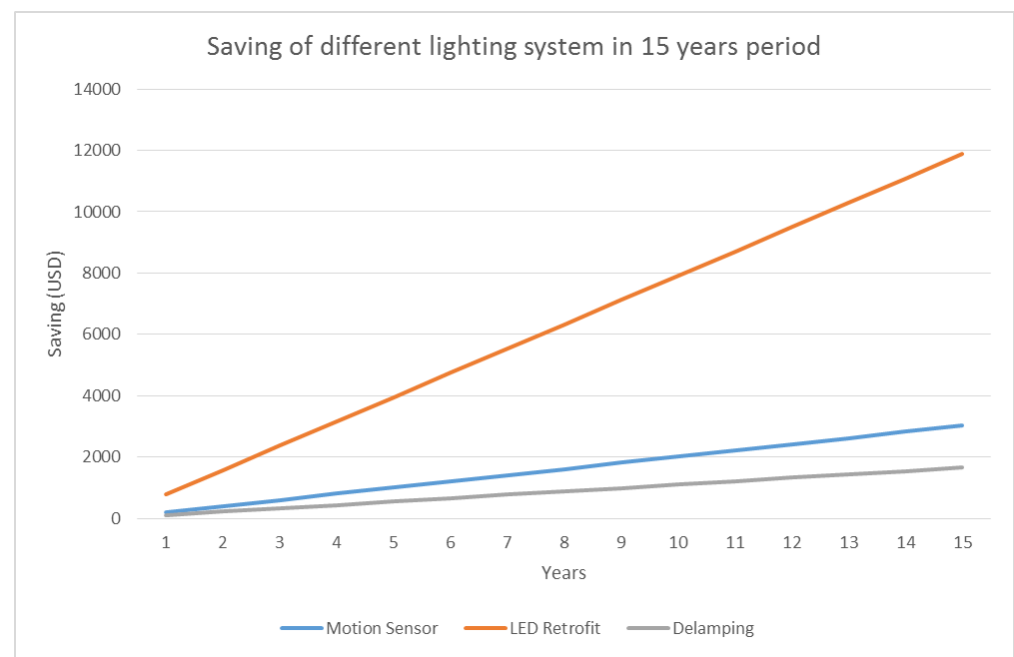

Figure 7. Projection of saving for 3 different lighting system 


\section{CONCLUSION}

The measures in reducing greenhouse gas emission shown by the Malaysian government is unarguably one of the best measures in the region. Commercial and business building should take the opportunity to utilize all the measures not only to show their togetherness in creating healthier environment but also benefits them in overall operational cost through utility expenses. Nevertheless getting to the goal of reducing the utility bill requires some knowledge in energy efficiency. A simple method to realize the saving is through employee awareness talk of how switching off the light when not in use or closing the window when air conditioning is in operation can help the company. Even by replacing or planning the electric lighting installation with energy-efficient T5 fluorescent lamps-luminaires and CFL for task lighting can contribute to cost efficient lighting system [11]. Another method discussed in this paper also provides general rules of optimizing the illumination of lighting system in an office area without investing in LED's or energy management system product. However reducing the lamp through this activities should not compromise the minimum illumination level required by the office area. Same rule applies to the initiative to change the setpoint of air-conditioning. If the employee become uncomfortable while implementing energy saving activities, then it is called scarifying a little comfort zone for the benefits of the company. If this kind of direction is shown to the employee, the company may faces low employee productivity in the future. Investing in energy efficiency system can be expensive but the payback period is within 2-7 years. If the company has the capital to proceed with such initiative, then it would give high good impression of the company's reputation in contributing towards clean and greener community. As for the conclusion, Delamping method helps small company to save electricity bills and contribute to the environment with minimum investment.

\section{ACKNOWLEDGEMENTS}

I would like to thanks to Universiti Teknikal Malaysia Melaka through the Research and Innovation Centre and Fakulti Teknologi Kejuruteraan for its financial support in this research. This paper financed under UTeM matching grant GLUAR/CARVELLO/2017/FTK-CERIA/I00023. Special thanks to Kementerian Pendidikan Tinggi Malaysia for offering various research grants opportunity to our research.

\section{REFERENCES}

[1] Ab Halim M.F.M., Azlan U.A.-A., Harun M.H., Annuar K.A.M., Mustafa M., Johari S.H., Abdullah A.R., Hushim M.F., "Lighting Retrofit Scheme Economic Evaluation," Indonesian Journal of Electrical Engineering and Computer Science., vol. 5, no. 3, pp. 496-501, 2017.

[2] Ministry of Energy, Green Technologies and Water National: "Energy Efficiency Action Plan Draft Final Report 2014", 2014.

[3] Amory Lovins and Rocky Mountain Institute: "Bold Business Solutions for the New Energy Era. Major Commercial Building Category Expense by Building Type for Commercial Sector," Reinventing Fire, 2011.

[4] U.S. Energy Information Administration: "Electricity Consumption by Sector," Annual Energy Outlook 2014 Early Release, 2014.

[5] Yoshihiro Kasahara, Mitsunori Miki and Masato Yoshimi: "Preliminary Evaluation of the Intelligent Lighting System with Distributed Control Modules," International Conference on Intelligent Systems Design and Applications, vol. 11, 2011.

[6] J. Fraytag, M. F. da Silva, N. B. Chagas, R. N. do Prado, and M. A. Dalla Costa: "Lighting Systems Energy Efficiency based on Different Human Visual Conditions, ” IEEE/IAS International Conference on Industry Applications, vol.9, 2010.

[7] Prashant Kumar Soori, Safaa Alzubaidi: "Study on Improving the Energy Efficiency of Office Building's Lighting System Design," IEEE GCC Conference Exhibition Dubai, 2011.

[8] Surasak Panj Avaranont, Pornrapeepat Bhasaputra, Woraratana Pattaraprakorn, Kitti Tirawannavit, Chaiyapat Kumpeerakupt, Somkuan Rimsmutchai, Natapongkorn Pawanawichien: “The Optimal Design of Lighting Systems for Designated Office Building in Thailand According to Ministerial, the Type or Size of Building Standards and Rules and Procedures, Building Design for Energy Conservation, Act B.E.2552," International Conference and Utility Exhibition on Power and Energy Systems: Issues \& Prospects for Asia, 2011

[9] R. Lakshmanan, A. K. Ramasamy, S. K. Ahmed and R. Sinnadurai, "Efficient illumination design and energy saving through occupancy control for building," IEEE Conference on Sustainable Utilization and Development in Engineering and Technology (CSUDET), Selangor, pp. 80-85, 2013.

[10] American Society of Heating, Refrigerating, and Air-Conditioning Engineers: "Standard 90.1-2013," Energy Standard for Buildings Except Low-Rise Residential Buildings, 2010.

[11] M.-C. Dubois, Å. Blomsterberg: "Energy Saving Potential and Strategies for Electric Lighting in Future North European, Low Energy Office Buildings: A Literature Review,” Energy Buildings, vol.43. no. 10, 2011. 


\section{BIOGRAPHIES OF AUTHORS}
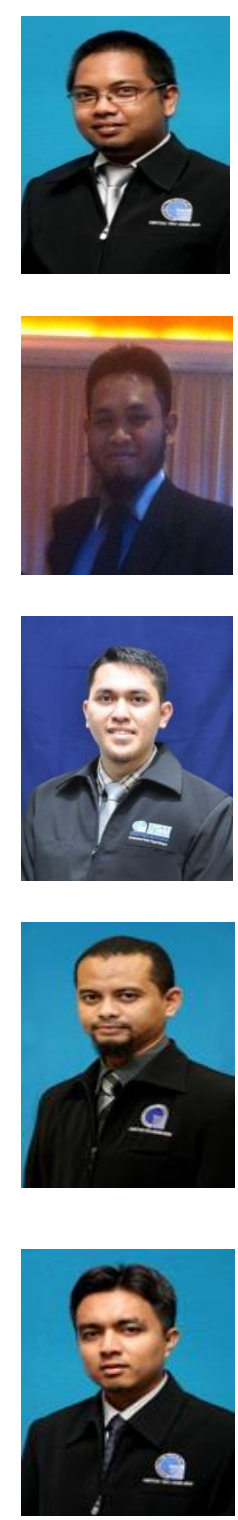

Mohd Firdaus bin Mohd Ab Halim worked in Sony, Intel and Qimonda before joining research institution in 2012. The preference of his research were mainly on energy efficiency, motor control and electrical vehicle. Besides that he led more than 5 research grants and contribute to more as member in 10 research grant. He is now an important member of Faculty of Engineering Technology, $\mathrm{UTeM}$

Dr.-Ing. Mohd Nazri Bin Omar was awarded Ph.D in Energy Engineering last 2015 from the Technical University Berlin, Germany. A member of the Energy Insitute of the UK just recently, he is a Professional Technologist (Ts.) of the Malaysian Board of Technologist (MBOT). He is now working on a Bio-Diesel Plant (of the National Professors' Council) as well as several Private-Public Research Network (PPRN) grants, and teaching Thermodynamics for the School of Manufacturing Engineering's students.

Mohamad Haniff bin Harun received his B.Eng degree in Mechatronic Engineering from Universiti Teknikal Malaysia Melaka (UTeM), in 2010. He received the M. Eng degree in Electrical Engineering also from Universiti Teknikal Malaysia Melaka (UTeM), in 2013. Currently he is a Lecturer at Universiti Teknikal Malaysia Melaka (UTeM) and his interests are in machine vision system, mechatronic system and automation system

Muhamad Faizal bin Yaakub CEng, MIET was born in Johor, Malaysia in 1981. In 2004 he received his B.Eng (Hons) degree in Electric-Electronic engineering form Universiti Teknologi Malaysia and in 2013, he received his M.Eng in Electrical Engineering form Universiti Tun Hussein Onn Malaysia. He has 5 years' experience in ASIC Test and Development in STMicroelectronics. He is currently a researcher and lecturer in Universiti Teknikal Malaysia Melaka. He is registered as Chartered Engineer with UK Engineering Council and a member of Institute of Engineering and Technology. His research interest includes the field of multilevel inverter, sustainable energy technology and power quality engineering.

Khalil Azha Mohd Annuar, received his B.Eng degree in Electrical Engineering (Electronic) from Universiti Teknologi Malaysia (UTM), in 2006. He received the M.Eng degree in Mechatronics and Automatic Control engineering also from UTM, in 2014. Currently, he is a Lecturer at Universiti Teknikal Malaysia Melaka (UTeM) and his interests are in control system and artificial intelligent. 